\title{
Problems of the Phenomenon of Empireness in the Postcolonial Era and Its Expression in Various Forms of Media Imperialism via the Examples of the USA, Japan and Russia
}

\author{
Yazovskaya Olga ${ }^{1}$, Gudova Iuliia ${ }^{2}$ \\ ${ }^{1}$ Ural Federal University, Ekaterinburg, Russian Federation \\ ${ }^{2}$ Ural Federal University, Ekaterinburg, Russian Federation \\ Corresponding author:Yazovskaya Olga, yazolga@gmail.com
}

\begin{abstract}
The aim of the study is to define the phenomenon of empireness and to define its role in the era of postcolonialism. We consider the forms of empireness in the form of media imperialism in relation to the policies and development trends of the United States, Japan and Russia. As a result of the research based on the works of M. Beissinger, E. M. Wood, G. Münkler and R. Rilling, we offer a definition of the concept of empireness as a variable quality, a property of a state that claims to dominate in a globalized world, manifested in the form of imperial ambitions in the politics of cultural imperialism. Further it is shown that currently the leading form of cultural imperialism is media imperialism (G. Münkler, G. Schiller and O. Boyd-Barrett). In this regard, the manifestations of imperialism via the examples of the USA, Japan and Russia were examined from the position of media imperialism. Everything allowed us, on the one hand, to outline a general theoretical methodology for working with empireness, and on the other hand, to show the possibilities of its application with specific examples, having determined that modern media in the form of mass media and mass culture can be successfully used as tools for realizing imperial ambitions.
\end{abstract}

Keywords: empireness, postcolonialism, media imperialism, the USA, Japan, Russia

\section{Introduction}

In this study, we set out to comprehensively consider the phenomenon of empireness: the main characteristics, its role in the era of postcolonialism, as well as the leading form of its manifestation in the form of media imperialism via the examples of such countries as the United States, Japan and Russia. In this regard, our research is divided into two parts: theoretical and practical. 
We begin the theoretical part by considering the role of an empire in the postcolonial discourse, then dwell separately on general approaches to defining the concept of an empire and variants of its classifications. Further, we formulate directly the very concept of empireness and consider the features of its manifestation in the politics of media imperialism. We characterize media imperialism itself as the leading form of cultural imperialism and trace the relationship between media imperialism and soft policy.

In the practical part, we analyse the manifestation of empireness in the forms of media imperialism using a number of examples. First of all, we characterize the specifics and stages of development of media imperialism in relation to the United States as a country where media and communications play a significant role in a number of political and social processes. Next, we turn to the example of Japan, as a representative of the Asian region, and analyse its features of the manifestation of imperialism in the form of media imperialism and soft policy, both in the form of direct export of mass culture, and in the form of the activities of various foundations that popularize it. We conclude the practical part with an analysis of imperialism via the example of Russia where we observe the emerging tendencies of media imperialism in the form of the promotion of modern cinema and cartoons and the activities of a number of government organizations.

\section{Theoretical approaches to the concept of empireness}

Next, we will consider the theoretical framework that will allow us to define empireness in relation to postcolonial countries. To do this, we will consider contemporary postcolonial discourse and the role that empires play in it. Then we will consider the issue of typologizing empires, present a working version of the definition of empireness and analyse the features of the manifestation of empireness within the framework of media imperialism.

\subsection{Empires in the postcolonial discourse}

In recent years, a number of domestic and foreign researchers dealing with modern political processes have noted a revival of interest in the concept of empire and issues of its functioning, including in relation to the modern postcolonial era, and, moreover, are discovering its new forms. The pioneer of these studies is Edward Said who in the 1980s proposed the concept of orientalism and drew attention to the relationship between culture and imperialism [Said, 1993; 1978]. 
Within the framework of modern research, one can single out the work of Stephen Slemon who proposed to systematize the postcolonial scientific discourse based on the analysis of the nature of the relationship between the colonizing and the colonizing which can occur through direct influence, or through institutional regulators, or through the semiotic field [Slemon, 1994]. In general, according to the author, the main direction of postcolonial research had examined the power of the state apparatus and the political and economic relations of a state with satellites, taking the relationship between the empire and its colony as a model of their interaction. April Biccum focuses on the discourse of history and development as a problematic point of the concept of empire and proposes to highlight the globalized empire as a modern form of empire in the post-colonial era [Biccum, 2009]. Turning to the modern discussion of the concept of empire and its modern forms, Mark Beissinger proposes to introduce the concept of empireness into scientific circulation which will allow us to not only state the existence of new forms of empire, but to present it as a kind of variable quality, a change of state, a claim for domination. He notes: '... an empire is a situation in which claims to submission to imperial control are becoming widespread, gaining weight and becoming more hegemonic' [Beissinger, 2005, 20].

Thus, clarification of the features of the new globalized form of empire becomes a significant problem in postcolonial research; it becomes necessary to single out a separate concept of imperialism as its characteristic that requires more detailed theoretical consideration.

\subsection{Uncertainty of the concept of empire}

A significant difficulty in defining empireness is created by the vagueness of the very concept of empire. Historical and political approaches to understanding the empire dominate in Russian-language studies. Within the framework of the historical approach, V.E. Matveev examines the development of the concept of empire in Russian science in the period of 1989-2006. and notes that in the XXI century the conceptual field of the empire is expanding and meta-concepts appear that go beyond the realm of historical science itself. These include myth, memory, diaspora, war, word, gender, emotions, etc. [Matveev, 2008, 19]. Within the framework of the political science approach, as S. I. Kaspe notes, an empire is most often understood as a political system that covers large and centralized territories. The centre of such a system can be embodied in central political institutions or in the personality of the emperor. The key characteristics of the empire, according to S. I. Kaspe, there are 
ethno-cultural heterogeneity, vast territories, a special structure of social ties and institutional interactions, an internally heterogeneous political culture [Kaspe, 2001, 24-25]. Both approaches point to the possibility of transforming modern forms of empires.

The question of the typology of empires is also rather problematic. When considering specific historical examples, a large number of subtypes of empires can be distinguished: empires of land or sea, military or economic, dictatorial or democratic, bureaucratic, national, territorial, colonial or continental, etc. Scottish historian N. Ferguson suggests taking into account a large number of different factors: political system, goals, public goods provided, methods of government, economic system, distribution of benefits and nature of society. Such a broad understanding leads to the fact that in the entire history of mankind according to the author about 70 states can be referred to as empires, but at the same time he does not single out empireness as their characteristic [Ferguson, 2005, 19-20].

An alternative typologization, taking into account the current situation of postcolonialism, is proposed by E. M. Wood. She notes that throughout the history of mankind there have been three types of empire: empires of property where power was retained through ownership of land and its redistribution; trading empires whose main expansionist project was the search for new trade routes and places; empires of capital based on the nation state. Empireness in this context is understood as something that characterizes the empire making this state possible. And in the case of the third type of empire, it is based on three aspects: 1) direct power is dependent on the market for economic agents; 2 ) the separation of economics and politics makes possible a manifold increase in the power of capital; 3) the difference between the capitalist "centre" and "periphery", "core" and "edge", "the internal" and "the external" is formed by economic levers. Global forms of empires can also be attributed to the third type - the empire of capital [Wood, 2003].

\subsection{Definition of the concept of empireness}

German-speaking authors work with the concept of empireness in more detail. The most famous political scientist is Herfried Münkler [Münkler, 2005]. He uses the concept of empireness (German Imperialität) in relation to the empire in the same sense as statehood - to the state. Thus, empireness acts as a certain set of properties and characteristics that form an empire, although empireness itself does not replace statehood, but is built on top of it. This set includes functions of boundaries where the degree of influence 
of the centre on the periphery is taken into account; distribution of rights characterized by heterogeneity in favour of the centre; more often random circumstances of occurrence; extension in time and space, and in relation to space we are also talking about the sphere of influence; impossibility of observing neutrality in political terms; special logic of empires, allowing interference in the affairs of nearby satellite states. According to Münkler, these properties of empires are characteristic not only of classical empires of the past, but also of modern globalized forms.

Rainer Rilling, a political sociology professor, has offered the most detailed analysis of empireness for modern forms of empire, or, as he describes them, imperial projects [Rilling, 2008]. He considers the first aspect in relation to the classical characterization of the empire through the delimitation of the centre and the periphery. The interaction between the centre and the periphery is organized hierarchically where the relationship with the centre becomes more important than the relationship between the individual parts of the periphery. Rilling notes the delimitation of the periphery: there is an internal periphery whose existence is presented as part of the civilized world in accordance with its norms and rules, and an external periphery which is understood as something excluded from civilization, from an empire. Other aspects of empireness are associated with the characteristics of the centre and periphery. Within the empire, an illusory social unity is formed with an actual internal diversity and heterogeneity. Empire allows one to manage this plurality, relying on state institutions and power actors, and on its intermediaries and supporters. The stability of the empire is ensured by the moral and political side of its power, when military intervention is justified by high moral potential, for example, the defense of democracy or the prevention of genocide.

Another factor of empireness is the scaling of power through the expansion of territories with their resources which makes it possible to build up the economic potential. This gives rise to another feature of empireness in the form of a desire both to expand in the spatial sense, and to deepen as a qualitative strengthening of the nature of influence. Thus, the boundaries of the empire become blurred due to the constant process of inclusion and exclusion of territories and spheres of influence. And the most significant feature of empireness is the desire for a world order and the ability to establish it, and today we need to talk about the desire for globalized projects and the solution of geopolitical issues. Rilling unites the presented characteristics 
of empireness in the form of a model of an imperial project - the general structure of new forms of empire which is characteristic of the era of postcolonialism.

\subsection{The manifestation of empireness in the politics of cultural imperialism}

Empireness as an intention to dominate in different spheres and for different types of empires including new forms of empires of the postcolonial era can be traced in the politics of cultural imperialism. In our view, such a policy is the main way of exercising power in modern relations between states. Cultural imperialism has been studied by many scholars, for example, by E. Said [Said, 1993], J. Galtung [Galtung, 1971], S. P. Mains [Mains, 2009], G. Münkler [Münkler, 2005], O. Boyd- Barrett [Boyd-Barrett, 2015] and others. We, in turn, define cultural imperialism as follows: it is the subordination of the entire integrity of the cultural system and its individual components (such as geography, state cultural policy, visual epistemology, communications) to the power of the empire, and broadcasting this power on a global scale. Most often, the policy of imperialism is directed at other countries, so one state in this case tries to subjugate or exert a significant influence on another country through culture.

The concept of the relationship between empireness and cultural imperialism is based on the concept of the importance of symbolic boundaries which are described by Münkler [Münkler, 2005]. Symbolic borders play a major role in the empire's striving to strengthen its influence in the foreign policy opposition of the main and subordinate state. In such a situation, it is precisely the influence through culture that makes it possible to influence the sphere of the symbolic. In modern realities, a country with imperial intentions should occupy a leading position in all spheres of culture: not only in the level of economic development and the arms race, but also in the Nobel Prizes, the ranking of universities, the number of Oscars, the Olympic medal standings, etc. [Münkler, 2005, 54]. This also includes medical developments. That is why it becomes extremely important which country will be the first to create a vaccine against COVID-19 and offer it for use around the world. Thus, according to the author, a country in the postcolonial era which possesses empireness is in its form a state in which the features of the empire are transferred to the sphere of the symbolic, for example, the boundaries of influence; such a country has the aspiration to become an empire and builds its foreign policy based on the model of relations between the dominant Centre and the dependent Periphery. 
2.4.1. Media imperialism as the leading form of cultural imperialism. Within the framework of cultural imperialism, the focus is increasingly made on the form of media imperialism, due to the fact that the media sphere in the era of postcolonialism is becoming an important instrument of influence of one country on another or one region on another. Herbert Schiller was one of the first to study the influence of the media in the 1970s considering the United States as an example. This theme is the subject of his works, namely Mass Communications and the American Empire, Manipulators of Consciousness, as well as 'Communications and Cultural Dominance' [Schiller, 1969; 1973; 1976].

According to Schiller, one of the important attributes of power is the flow of information that goes from the centre to the periphery, therefore, in order to achieve domination, it is necessary to seize the media, including television. At the same time, the cultural and communication sector of the world system is developing in accordance with the goals and objectives of the system of cultural imperialism. Thanks to this, cultural and information products that advertise the values of the system are distributed within the global capitalist economy with the help of transnational corporations. They are, according to Schiller, the institutional basis of media imperialism. So, the centre begins to dominate the periphery in the field of culture and information due to the transmission of its ideology through modern means of communication. In particular, the content carries the ideological features of the world economy which makes it possible to effectively advertise the values of the Centre's system. In general terms, it turns out that 'the content and style of programs (TV programmes - Yu. G.), no matter how they are adapted to local conditions, bear the ideological imprint of the main centres of the world capitalist economy' [Schiller, 1976, 10].

O. Boyd-Barrett continues to study the topic of media imperialism on the example of the United States in the 21st century. In his opinion, with the help of the media, one can not only implement and promote the processes of imperialism, but also transform and even weaken it. In the relationship between the media and the empire, the opposite direction of influence is also possible when the empire begins to model the media themselves [Boyd-Barrett, 2015, 14].

Media imperialism also reveals itself in the framework of diplomatic processes since the sphere of media allows you to broadcast outside a favourable image of the country and in this way to influence decision-making in foreign 
policy issues. This mechanism of influence, regardless of the media, is called soft policy. American political scientist Joseph Nye defines this type of policy as follows: 'What is soft policy? It is the ability to get what you want through attraction, not coercion or payments. This stems from the attractiveness of the country's culture, political ideals and politics. When our policies are seen as legitimate in the eyes of others, our soft policy is strengthened' [Nye, $2004, \mathrm{X}]$. Soft policy in this sense does not always pursue the goal of domination in the media sphere, as in the case of media imperialism, and is a broader concept. Nevertheless, since media imperialism presupposes the influence of the centre on the periphery through the broadcasting of information approved by the centre designed to form a favourable image of the centre, then we can talk about the policy of soft policy in relation to new forms of empire.

\section{Specific examples of the manifestation of empireness in the forms of media imperialism via the examples of the United States, Japan and Russia}

In this section, we will dwell in more detail on specific examples of the manifestation of empireness that we find in the forms of media imperialism in relation to the countries such as the United States, Japan and Russia.

3.1. The manifestation of empireness via the example of the United States

The USA is one of the modern carriers of empireness. A number of researchers in the analysis of American policy of cultural imperialism focus on communication imperialism as its form, and they include J. Galtung [Galtung, 1971], P. Golding and P. Harris [Golding, Harris, 1997], D. Y. Jin [Jin, 2007], G. Schiller [Schiller, 1969, 1973, 1976]. According to Galtung's definition, one of the directions of communication imperialism is domination in the world communication networks and transportation of objects and ideas [Galtung, $1971,92]$. Since the end of the 20th century, communication imperialism has been implemented to a large extent in the field of media; therefore, it is also called media imperialism.

According to Shestakov [2012] and other researchers, the main distinctive feature of American communication imperialism is total control of the industry of production and distribution of information. The United States carries out cultural expansion controlling the production and distribution of a mass cultural product and norms on a global scale, and therefore with the help of mass art and technical means of its dissemination. The Korean scientist D. Y. Jin identifies the following instruments of expansion. Firstly, these are transnational 
corporations for the production, selection and distribution of news and series (fiction, documentary cartoon, popular science, etc.), as well as other television content. Secondly, these are corporations for the production of feature films and, thirdly, it is the industry for the production of gadgets and software for them. In addition, Jin identifies several periods in the development of US communication imperialism. At the first stage, the Americans independently produced a cultural product which then spread throughout the world; at the second stage, they were engaged in the dissemination of technical means for creating and broadcasting content, and at the third stage, they moved on to investing in the development of national telecommunication systems based on American programs and technologies. Let's consider these stages in more detail.

If at the first stage there was a one-way international flow of American-made films from the United States to the rest of the world, then at the second stage the United States were engaged in the dissemination of technical means of creating and broadcasting content gradually moving to investing in the development of national telecommunication systems based on American programs and technologies [Jin, 2007]... Media imperialism in this case is a conscious and organized effort by Western, especially American, communications conglomerates, which are necessary to maintain commercial, political and military superiority.

Jin examines the development of US communication imperialism using the example of South Korea. His research convincingly shows how South Korea, a periphery of US media content in the late 1950s, has levelled the flow of imports and exports of television programming since the mid-1990s. Due to the economic crisis, South Korea gradually reduced purchases of foreign content, foreign audio and visual products, and began to increase the production and export of Korean products. To do this, Korea had to develop its own programmes. There was an increase in the number of Korean programme producers and a decrease in the Western content. This has led to the strengthening and active development of local Korean media industries and to an increase in the export of Korean cultural products around the world, especially to China, Taiwan, Vietnam, Japan and Hong Kong. Thus, since 2002, TV program exports have exceeded imports for the first time [Jin, 2007]. Thus, the relations between the United States (Centre) and South Korea (Periphery), which were at the first stage, gradually began to move to the second, because South Korea no longer had a need for US media content due to import substitution in the media environment. 
In the second phase, the United States was also involved in the distribution of technical means of creating and broadcasting the content; transnational companies began to actively appear and develop, and they spread their cultural influence throughout the world as transnational media giants. Boyd-Barrett notes that the dominant position in the international film industry is occupied by Hollywood distribution studios and transnational conglomerates, for example, 21st Century Fox, Paramount, Sony Pictures, Walt Disney, Warner Bros [Boyd-Barrett, 2015, 121], and namely they own $40 \%$ of the revenues from world film production and distribution.

At the third stage, relations between the United States and other countries moved to investing in the development of national telecommunication systems based on American programmes and technologies. American media giants use local cultural resources to promote their products because people prefer to watch programmes in their own languages, so global media enterprises have to adapt to local cultures and connect with local partners to support their expansion [Jin, 2007, 763].

Thus, US dominance is growing rapidly in the form of investment and the flow of cultural products. It can be concluded that, as a result of such a communication-imperialist policy, national telecommunications fall into a triple dependence: on American funding, on the supply of American software and equipment, and on the American content and American licenses for the production of the national content.

\subsection{The manifestation of empireness in Japan}

Next, we will consider various forms of manifestation of empireness via the example of Japan and focus more on media imperialism and its manifestations in soft policy.

Japanese media imperialism is closely connected with the economic crisis of the 1990s and 2000s, when the classical system of Japan production began to fail and Japanese mass culture came to the fore and became an important segment of economic exports. In connection with the spread of the Internet, there is a growing interest in the novelties of Japanese animation, cinema, manga comics and video games among foreign fans. The producers and leaders of the country note the high export potential of such products. And if Japanese cinema gained worldwide recognition back in the 1950s, during its 'golden age', Japanese animation, primarily in the form of cartoons by the Dzibli studio, became an international discovery in the early 2000s [Katasonova, 2012, 311-336]. Against the background of these natural pro- 
cesses, Japanese governments decided to increase their influence in the world through soft policy developing the Cool Japan concept and opening in 2013 a public-private fund of the same name the purpose of which is to promote Japanese media content, fashion and cuisine (www.cj -fund.co.jp).

In general, the Japanese Foreign Ministry has been pursuing a policy of soft policy for quite a long time working in different directions. According to the Russian Japanese scholar A. E. Kulanov, the exchange of people and programs of educational and sports exchanges, exchanges in the fields of culture, art, science and Japanese studies abroad are considered to be the most effective direction. Among other things, it is worth noting not only exchanges of outstanding personalities, but also various youth exchange programmes implemented by various foundations (Japan Foundation, Japan-Russia Centre for Youth Exchanges) [Kulanov, 2007]. And if in the 1970-1980s more emphasis was placed on exchanges in the field of traditional arts, then now the promotion of mass culture is also underway [Katasonova, 2012, 313-317; MacGray, 2002]. The second area is public relations which includes special programmes to develop understanding and promotion of the image of Japan and the foreign press about Japan. This programme also includes the activities of various centres that promote the study of the Japanese language and culture abroad. The most significant news and educational Internet resources about Japan for Russia are the website of the Japanese Embassy in Russia (https:// www.ru.emb-japan.go.jp), the Web-Japan portal (https://web-japan.org), the Japan Foundation website (https://jpfmw.ru/), the Nippon.com news portal (https://www.nippon.com/ru/), and others.

The key agent of soft policy, according to S. V. Chugrov, is the Japan Foundation government organization [Chugrov, 2015, 62]. The Foundation was founded in 1972 as an independent administrative organization of the Ministry of Foreign Affairs of Japan; since October 1, 2003, the Foundation has been a legally independent organization. Its main activities are the promotion of cultural exchange, the Japanese language and scientific research about Japan abroad, as well as assisting in the collection and provision of information on international exchange. Among other things, it assists in the organization of Japanese film festivals in different countries.

In general, we observe a fairly clear orientation of Japan's soft policy towards media imperialism in the form of the spread of Japanese mass culture and a favourable image of the country through the activities of the Ministry of Foreign Affairs, the Japan Fund and the Cool Japan fund. 


\subsection{The manifestation of empireness via the example of Russia}

As a final example, let us consider the forms of manifestation of empireness in Russia, also referring to media imperialism and its manifestations in soft policy. Media imperialism in Russia is still gaining momentum, and to a greater extent it is represented in the field of cinema and animation. Initially, individual film companies promoted only a few films to achieve greater commercial success, and in recent years, thanks to international film festivals and the work of producers, Russian films and cartoons have begun to gain popularity. Examples of this are Burnt by the Sun (1994, directed by N. Mikhalkov), Russian Ark (2001, directed by A. Sokurov), Return (2003, directed by A. P. Zvyagintsev), Stalingrad (2013, directed by F. Bondarchuk). Domestic cartoons are also popular, among other things "Cheburashka" (1971, directed by R. A. Kochanov), as well as the animated series "Masha and the Bear" (2007, directed by O. G. Kuzovkov, etc.) [Those who have conquered the world, 2018].

We also find some manifestation of media imperialism in the implementation of soft policy. In general, the policy of soft power in Russia, according to R.S. Mukhametov, is more focused on the export of education, as well as strengthening the position of the Russian language and popularizing Russian culture since these directions contribute to the creation of a positive image of Russia in the world [Mukhametov, 2010, 197]. Examples of this are the work of foreign branches of Russian universities, many of which are represented in the CIS countries, grants and scholarships for foreign students in Russia, as well as the system of Russian-national (Slavic) universities and state funds: International Humanitarian Cooperation (Rossotrudnichestvo) and the Russian World. And it is the last two organizations that use the tools of media imperialism to popularize Russian culture.

Rossotrudnichestvo traces its history back to the beginning of the 20th century when it was known as the All-Union Society for Cultural Relations Abroad. In its current form, the organization appeared by decree of the President of the Russian Federation in 2008 [Decree of the President of the Russian Federation dated 06.09.2008 No. 1315]. Representative offices of Rossotrudnichestvo operate in 81 countries including 74 Russian centres of science and culture and 24 representatives of the Agency as part of embassies. One of the activities of this organization is assistance in holding various cultural events, for example, exhibitions from the collection of the State Hermitage and the Russian Museum, organizing the Days of Russia, etc. (see: http://rs.gov.ru). 
The Russkiy Mir Foundation was established by the Decree of the President of the Russian Federation in 2007 [Decree of the President of the Russian Federation of June 21, 2007 No. 796]. The main activities of the foundation are related to supporting the Russian language abroad which is facilitated by the work of Russian centres around the world. The Foundation also supports the Russian-language media, organizes contests that popularize journalistic activities sanctifying the features of the manifestation of Russian culture in the world, for example, the Correspondent of the Russian World television competition, the Co-Creation international competition for young journalists (see: russkiymir.ru).

In general, we can record a certain reorientation of Russia's soft policy towards the media in the form of promoting Russian modern cinematography and animation abroad, as well as the formation of a positive image of the country in the media through the activities of Rossotrudnichestvo and the Russkiy Mir Foundation.

\section{Results and discussion}

In general, within the framework of this study, we have carried out a thorough theoretical development of the concept of empireness in relation to the era of postcolonialism based on the scientific works of S. Slemon, E. Bikkum, M. Beissinger, E. M. Wood, G. Münkler and R. Rilling and thus obtained a working toolkit for identifying the degree of imperial intention of a country. In general, we can characterize empireness as a variable set of qualities or properties that characterize a state that claims to dominate in a globalized world which include: delimitation of the centre and the periphery; semi-permeability of borders and uneven distribution of rights in favour of the centre; the illusory nature of social unity with the actual internal heterogeneity of society; the presence of political control and the moral and political aspect of power; extension in time and space intensified by the desire to expand; the impossibility of maintaining neutrality in relations with other countries expressed in the form of logic justifying the legitimacy of intervention in the affairs of states based on moral justification.

Next, we traced the modern manifestations of empireness in the form of the policy of cultural imperialism whose leading form at the moment is media imperialism. We relied on the research by G. Münkler, G. Schiller and O. Boyd-Barrett. We characterized cultural imperialism as a mechanism that is the subordination of the entire integrity of the cultural system and its individ- 
ual components to the power of the empire and the transmission of this power on a global scale. In view of the fact that the field of media is gaining more and more importance in the era of postcolonialism, it is precisely such a form of cultural imperialism as media imperialism that is becoming the leading instrument of influence within the framework of imperial intention.

In addition, in the course of the study, we have examined specific examples of empireness in the form of media imperialism for countries such as the United States, Japan and Russia. With regard to the United States, we have found that media imperialism was initially defined there as communication imperialism and developed in three stages: starting from the simple export of cinematographic products, then the export of technical means for creating and broadcasting content, and then to investments in the development of national telecommunication systems based on American development. With regard to Japan, media imperialism finds its manifestation to a greater extent in the policy of soft power aimed at exporting various directions of Japanese mass culture, as well as promoting a favourable image of the country. As for the last example, here we noted the emergence of media imperialism in the form of the gradual advancement of Russian modern cinema and animation abroad, and the growing desire to create a positive image of the country in the world.

\section{Conclusion}

The work that we have done in the framework of this study made it possible to outline a general theoretical methodology for working with the concept of empireness in relation to the era of postcolonialism, and also to consider its manifestations in the form of cultural imperialism, the leading form of which is media imperialism. In general, we were also able to outline the forms of manifestation of empireness in the politics of countries such as the United States, Japan and Russia noting the leading role of the media in the form of media and mass culture.

The research results can be used to clarify the policy of soft power and diplomatic strategies not only for the United States, Japan and Russia, but also for conducting research on the nature and characteristics of the imperial influence of certain countries through mass culture and the media.

\section{Conflict of Interest}

The authors have no conflict of interest to declare. 


\section{Acknowledgment(s)}

The study was funded by RFBR according to the research project No 18-311-00273 titled Postcolonial Empireness in Mass Cultures of the USA, Japan and Russia.

\section{References:}

1. E. W. Said. Culture and Imperialism. Vintage, New York (1993).

2. E. W. Said. Orientalism. Pantheon, New York (1978).

3. S. Slemon. The Scramble for Post-Colonialism. De-Scribing Empire: Post-Colonialism and Textuality. Routledge, London, New York (1994), pp. 15-32.

4. A. R. Biccum. Theorising Continuities Between Empire \& Development: Toward a New Theory of History. Empire, Development and Colonialism: The Past in the Present. Boydell \& Brewer, Woodbridge, Rochester (2009), pp. 146-160.

5. M. R. Beissinger. Rethinking Empire in the Wake of Soviet Collapse. Ethnic Politics After Communism. Cornell University Press, Ithaca, London (2005), pp. $14-45$.

6. V.E. Matveev. Kontsept "imperiya" v sovremennoy nauchnoy literature : avtoreferat dis... kandidata istoricheskikh nauk : 07.00.09 [The concept of "empire" in modern scientific literature: abstract dis... candidate of historical sciences: 07.00.09]. Tom. gos. un-t, Tomsk (2008).

7. S. I. Kaspe. Imperiya i modernizatsiya: Obshchaya model' i rossiyskaya spetsifika [Empire and Modernization: General Model and Russian Specificity]. ROSSPEN, Moscow (2001).

8. N. Ferguson. The Unconscious Colossus: Limits of (\& Alternatives to) American Empire. Daedalus, 134 (2) (2005), pp. 18-33, 10.1162/0011526053887419.

9. E. M. Wood. Empire of Capital. Verso, London, New York (2003).

10. H. Münkler. Imperien: Die Logik der Weltherrschaft — vom Alten Rom bis zu den Vereinigten Staaten. Rowohlt Berlin Verlag GmbH, Berlin (2005).

11. R. Rilling. Risse im Empire. Dietz Verlag Berlin GmbH, Berlin (2008).

12. J. Galtung. A Structural Theory of Imperialism. Journal of Peace Research, 8 (2) (1971), pp. 81-117, 10.1177/002234337100800201

13. S. P. Mains. Cultural imperialism. International Encyclopedia of Human Geography, 1 (2009), pp. 322-329, 10.1016/B978-008044910-4.00082-1

14. O. Boyd-Barrett. Media Imperialism. SAGE Publications Ltd., London (2015).

15. H.I. Schiller. Mass communication and American empire. Augustus M. Kelley Publishers, New York (1969).

16. H. I. Schiller. The Mind Managers. Beacon, Boston (1973). 
17. H. I. Schiller. Communication and cultural domination. International Arts and Sciences Press, White Plains, New York (1976).

18. J. S. Nye. Soft Power. The Means to Success in World Politics. Public Affairs, New York (2004).

19. P. Golding, P. Harris. Beyond cultural imperialism: globalization, communication and the new international order. SAGE Publications Ltd., London (1997).

20. D. Y. Jin. Reinterpretation of cultural Imperialism: emerging domestic market vs continuing US dominance. Mass Culture and Society, 29 (5) (2007), pp. 753-771, 10.1177/0163443707080535

21. V.P. Shestakov. Amerikanskaya kul'tura: $\mathrm{v}$ poiskakh natsional'noy identichnosti (Chast' 1) [American Culture: Searching National Identity (Part 1)]. Journal of Cultural Research, 4 (10) (2012), p. 9.

22. E. L. Katasonova. Yapontsy v real'nom i virtual'nom mirakh: Ocherki sovremennoy yaponskoy massovoy kul'tury [The Japanese people in the real and virtual worlds. Essays on modern Japanese mass culture]. Vostochnaya literature, Moscow (2012).

23. A.E. Kulanov. Kul'turnaya diplomatiya Yaponii [Japan's Cultural Diplomacy]. Yearbook Japan, 36 (2007), pp. 116-130.

24. D. MacGray. Japan's Gross National Cool. Foreign Policy, 130 (2002), pp. 44-54.

25. S. V. Chugrov. Myagkoe prityazhenie Yaponii [Soft Attraction of Japan]. Polis. Political Studies, 6 (2015), pp. 53-67.

26. Pokorivshie mir: luchshie russkie fil'my, populyarnye za rubezhom [Those who conquered the world: the best Russian films popular abroad]. Vysotskaya Life. 2018. https://www.jvlife.ru/articles/1498-pokorivshie- mir-luchshie-russkie-filmypopulyarnye-za-rubezhom (Accessed 27 April 2020).

27. R.S. Muhametov. Kul'tura kak instrument vneshney politiki Rossii [Culture is an instrument of foreign policy of Russia]. Izvestia Ural Federal University Journal. Series 1. Issues in Education, Science and Culture, 86 (1) (2011), pp. 193-198.

28. Decree of the President of the Russian Federation of 6 September 2008 No. 1315. O nekotorykh voprosakh gosudarstvennogo upravleniya v oblasti mezhdunarodnogo sotrudnichestva [About some issues of public administration in the field of international cooperation]. URL: http://www.kremlin.ru/acts/bank/28020 (Accessed 28 April 2020).

29. Decree of the President of the Russian Federation of 21 June 2007 No. 796. O sozdanii fonda "Russkiy mir" [About the establishment of the "Russkiy Mir" Foundation]. http://www.kremlin.ru/acts/bank/25689 (Accessed 28 April 2020). 